\title{
HUBUNGAN ANTARA MOTIVASI BELAJAR DAN KEAKTIFAN \\ BELAJAR DENGAN HASIL BELAJAR IPA SISWA KELAS V SD
}

\author{
I Made Tegeh ${ }^{1}$, Ni Luh Ariesti Pratiwi ${ }^{2}$,Alexander Hamonangan Simamora ${ }^{3}$ \\ Universitas Pendidikan Ganesha \\ imadetegehderana@yahoo.com
}

\begin{abstract}
ABSTRAK
Hasil belajar dipengaruhi oleh beberapa faktor, dua diantaranya adalah motivasi dan keaktifan belajar. Kurangnya motivasi dan keaktifan siswa dalam mengikuti kegiatan pembelajaran mempengaruhi hasi belajar siswa. Penelitian ini bertujuan untuk mengetahui: 1) hubungan yang signifikan antara motivasi belajar dengan hasil belajar IPA siswa kelas V SD Gugus XII Kecamatan Buleleng, 2) hubungan yang signifikan antara keaktifan belajar dengan hasil belajar IPA siswa kelas V SD Gugus XII Kecamatan Buleleng, 3) hubungan yang signifikan antara motivasi belajar dan keaktifan belajar dengan hasil belajar IPA siswa kelas V SD Gugus XII Kecamatan Buleleng. Jenis penelitian ini adalah penelitian ex post facto yaitu penelitian yang dilakukan untuk meneliti peristiwa yang telah terjadi dan bersifat korelatif. Populasi penelitian ini adalah siswa kelas V di SD yang terdapat pada Gugus XII Kecamatan Buleleng tahun ajaran 2018/2019 dengan sample 150 siswa. Pemilihan sampel dilakukan dengan teknik purposive sampling. Pengumpulan data dalam penelitian ini dilakukan menggunakan metode non-tes, data yang diperoleh dianalisis menggunakan analisis statistik deskriptif dan regresi. Hasil penelitian menunjukan bahwa, 1) terdapat hubungan yang signifikan antara motivasi dengan hasil belajar IPA diperoleh koefisien korelasi R sebesar 0,768 dan sumbangan variabel kontribusi sebesar $59,1 \%, 2$ ) terdapat hubungan yang signifikan antara keaktifan dengan hasil belajar IPA diperoleh koefisien korelasi R sebesar 0,658 dan sumbangan variabel kontribusi sebesar 43,3\%, 3) secara bersama-sama terdapat hubungan yang signifikan antara motivasi dan keaktifan dengan hasil belajar IPA siswa kelas V SD Gugus XII Kecamatan Buleleng diperoleh koefisien korelasi R sebesar 0,849 dan sumbangan variabel kontribusi sebesar 72,1\%.
\end{abstract}

Kata Kunci: Motivasi, Keaktifan belajar, dan Hasil Belajar IPA

\section{ABSTRACT}

Learning outcomes are influenced by several factors, two of them are motivation and the activeness of learning. The lack of motivation and students' activeness participating in learning activities affects student learning outcomes. 
This study aims to determine: 1) the significant relationship between learning motivation and Science learning outcomes of fifth grade students of SD Gugus XII Buleleng Subdistrict, 2) the significant relationship between learning activeness and Science learning outcomes of fifth grade students of SD Gugus XII Buleleng Subdistrict, 3) the significant relationship between learning motivation and learning activeness with science learning outcomes of fifth grade students of SD Gugus XII Buleleng Subdistrict. This type of research is ex post facto research, namely research conducted to examine events that have occurred and are correlative. The population of this study was fifth grade students in elementary school taken from Gugus XII of Buleleng Subdistrict 2018/2019 school year with the samples of 150 students. Sample selection was done by purposive sampling technique. Data collection in this study was conducted by using non-test methods, the data obtained were analyzed using descriptive statistical analysis and regression. The results show that, 1) there is a significant relationship between motivation and learning outcomes of science obtained $\mathrm{R}$ correlation coefficient of 0.768 and contribution of variable contributions of $59.1 \%, 2)$ there is a significant relationship between activeness and learning outcomes of science obtained $\mathrm{R}$ correlation coefficient of 0.658 and contribution of variables contributing $43.3 \%, 3$ ) there is a significant relationship between motivation and activeness simultaneously with science learning outcomes of fifth grade students of SD Gugus XII Buleleng Subdistrict obtained R correlation coefficient of 0.849 and variable contribution of contributions of $72,1 \%$.

Keywords: Motivation, Learning Activity, and Science Learning Outcomes

\section{PENDAHULUAN}

Pendidikan pada era sekarang sangatlah penting, untuk kemujuan generasi bangsa yang lebih baik. Pendidikan adalah salah satu tolak ukur meningkatkan kualitas sumber daya manusia (SDM) yang unggul, semakin baik pendidikan yang diperoleh semakin baik pula kualitas sumber daya manusia (SDM). Pendidikan selalu berkaitan dengan sekolah dan proses belajar mengajar. Belajar adalah suatu proses yang ditandai dengan adanya perubahan-perubahan pada diri seseorang. Perubahan sebagai hasil dari proses belajar dapat ditunjukan dalam berbagai bentuk seperti berupa pengetahuan, pemahaman, sikap, dan tingkah laku, kecakapan, kebiasaaan, serta perubahan aspek-aspek lain (Sudjana, 1989: 5). 
Seorang anak yang tidak mengalami perubahan setelah belajar maka anak tersebut belum mengalami proses belajar secara optimal sehingga menyebabkan anak tersebut mendapatkan hasil belajar yang kurang baik. Hasil belajar dipengaruhi oleh beberapa faktor yang menjadi pemicu baik/buruknya hasil belajar yang diperoleh. Motivasi belajar meruapakan faktor yang mempengaruhi hasil belajar siswa. Menurut Achyanadia (2013) motivasi belajar adalah dorongan dalam diri seseorang untuk memenuhi keinginan dan tujuan belajar. Setiap siswa memilki motivasi yang berbeda-beda dalam belajar, siswa yang memiliki motivasi belajar akan terdorongan untuk belajar serta mengerjakan tugas yang diberikan guru sedangkan sebaliknya siswa yang tidak memiliki motivasi dalam belajar akan tidak terdorongan untuk belajar serta malas mengerjakan tugas yang diberikan oleh guru. Selain dipengaruhi oleh motivasi ada faktor lain yang mempengaruhi hasil belajar yaitu keaktifan dalam belajar.

Menurut Ramlah,dkk (2014), keaktifan belajar ditandai oleh adanya keterlibatan secara optimal, baik intelektual, emosi dan fisik. Siswa yang aktif dalam belajar akan menonjol dalam proses pembelajaran sedangkan siswa yang tidak aktif dalam belajar akan kurang menonjol dan pasif dalam pembelajaran. Motivasi dan keaktifan dalam proses belajar sangatlah penting agar tercapainya hasil belajar yang bagus. Kurikulum 2013 menuntut siswa untuk aktif dalam proses pembelajaran sedangkan guru hanya memfasilitas dan membimbing siswa dalam proses pembelajaran. Namun kenyataan dilapangan berbeda banyak siswa yang kurang aktif dan termotivasi dalam belajar khususnya pada pembelajaran yang bermuatan IPA.

Ilmu Pengetahuan Alam (IPA) sering disebut dengan Ilmu Alamiah. Sains atau IPA merupakan ilmu yang mempelajari tentang alam beserta isinya seperti tumbuhan, hewan maupun manusia. Menurut Simanjorang (2018) Ilmu Pengetahuan Alam (IPA) berkaitan dengan cara mencari tahu tentang alam secara sistematis, sehingga IPA bukan hanya penguasaan kumpulan pengetahuan yang berupa fakta-fakta, konsep-konsep, atau prinsip-prinsip saja tetapi juga merupakan suatu prosespenemuan. Berdasarkan pemaparan tersebut IPA sangat penting untuk dipelajari dan diajarkan kepada siswa dimulai dari jenjang pendidikan dasar. Melalui mata pelajaran IPA, siswa dilatih untuk memiliki keterampilan 
mengamati dan bereksperimen. Dalam pembelajaran IPA, siswa juga dilatih untuk memiliki sikap ilmiah seperti sikap jujur sehingga dalam proses pembelajaran IPA seorang guru harus mampu mengajarkan materi dan membentuk sikap siswa. Selain itu, pendidikan IPA menjadi dasar pemikiran siswa dalam memahami halhal terkait gejala-gejala alam yang terjadi di sekitar mereka.

Berdasarkan observasi awal, pembelajaran IPA kelas V SD Gugus XII Kecamatan Buleleng memiliki beberapa permasalahan. Hal ini diketahui dari hasil wawancara dengan guru kelas V SD Gugus XII Kecamatan Buleleng yaitu sebagai berikut. (1) pada siswa kelas V SD Gugus XII terdapat siswa yang pasif dalam mengikuti kegiatan belajar IPA dengan materi yang luas, (2) motivasi siswa dalam mengikuti mata pelajaran IPA yang berbeda antara masing-masing siswa, (3) siswa kurang aktif dalam bertanya dan menjawab pertanyaan guru,(4) semangat peserta didik untuk mendapat nilai di atas KKM yang berbeda pula, (5) kesadaran akan pentingnya menguasai materi pada mata pelajaran IPA dan kemauan peserta didik untuk menguasai materi IPA, yang berbeda antar masing masing siswa. Ketidaksamaan tingkat motivasi dan keaktifan belajar yang ada pada peserta didik, mengakibatkan tingkat pencapaian hasil belajar pada peserta didik dalam mempelajari materi pada mata pelajaran IPA berbeda.

Berdasarkan observasi awal, pembelajaran IPA kelas V SD Gugus XII Kecamatan Buleleng memiliki beberapa permasalahan. Hal ini diketahui dari hasil wawancara dengan guru kelas V SD Gugus XII Kecamatan Buleleng yaitu sebagai berikut. (1) pada siswa kelas V SD Gugus XII terdapat siswa yang pasif dalam mengikuti kegiatan belajar IPA dengan materi yang luas, (2) motivasi siswa dalam mengikuti mata pelajaran IPA yang berbeda antara masing-masing siswa, (3) siswa kurang aktif dalam bertanya dan menjawab pertanyaan guru,(4) semangat peserta didik untuk mendapat nilai di atas KKM yang berbeda pula, (5) kesadaran akan pentingnya menguasai materi pada mata pelajaran IPA dan kemauan peserta didik untuk menguasai materi IPA, yang berbeda antar masing masing siswa. Ketidaksamaan tingkat motivasi dan keaktifan belajar yang ada pada peserta didik, mengakibatkan tingkat pencapaian hasil belajar pada peserta didik dalam mempelajari materi pada mata pelajaran IPA berbeda. 
Selama pelaksanaan kegiatan observasi, peneliti juga melakukan pencatatan terhadap hasil belajar siswa kelas V di SD Gugus XII Kecamatan Buleleng. Berdasarkan hasil pencatatan dokumen didapatkan data bahwa rata-rata nilai IPA kelas V pada semester ganjil tahun pelajaran 2018/2019 kurang mencapai KKM di SD Gugus XII Kecamatan Buleleng. Hasil nilai UAS mata pelajaran IPA kelas V SDN 1 Banyuasri dari jumlah siswa 37 yang mencapai KKM 17 siswa (45,9\%) sedangkan yang tidak mencapai KKM 20 siswa (54,1\%). SDN 2 Banyuasri dari jumlah siswa 37 yang mencapai KKM 18 siswa (48,6\%) sedangkan 19 siswa $(51,4 \%)$ tidak mencapai KKM. SDN 3 Banyuasri dari jumlah siswa 13 yang mencapai KKM 6 siswa (46,2\%) dan 7 siswa $(53,8 \%)$ tidak mencapai KKM. SDN 4 Banyuasri dari jumlah siswa 36 yang mencapai KKM 16 siswa $(44,4 \%)$ sedangkan 20 siswa $(55,6 \%)$ tidak mencapai KKM. SDN 5 Banyuasri dari jumlah siswa 35 yang mencapai KKM 14 siswa (40\%) sedangkan yang tidak mencapai KKM 21 siswa (60\%). MIT Mardhatillah dari jumlah siswa 61 terbagi menjadi 2 kelas yaitu kelas VA dari 30 siswa yang mencapai KKM 13 siswa (43,3\%) sedangkan 17 siswa $(56,7 \%)$ tidak mencapai KKM. Sedangkan kelas VB dari 31 siswa yang mencapai KKM 14 siswa (45,2\%) sedangkan 17 siswa (54,8\%) tidak mencapai KKM.

Observasi yang dilakukan oleh peneliti tidak hanya memperoleh data tentang hasil belajar namun motivasi belajar dan keaktifan belajar di SD Gugus XII Kecamatan Banyuasri. Berdasarkan hasil pencatatan dokumen didapatkan data bahwa motivasi belajar dan keaktifan belajar pada siswa kelas V di SD Gugus XII Kecamatan Buleleng kurang motivasi dalam belajar IPA serta kurang aktif dalam belajar IPA. Persentase motivasi belajar IPA kelas V SDN 1 Banyuasri menunjukan $41 \%$ tingkat motivasi belajar IPA dari 37 siswa, SDN 2 Banyuasri menunjukan $40 \%$ tingkat motivasi belajar IPA dari 37 siswa, SDN 4 Banyuasri menunjukan 38\% tingkat motivasi belajar IPA dari 36 siswa, SDN 5 Banyuasri menunjukan $37 \%$ tingkat motivasi belajar IPA dari 35 siswa, dan MIT Mardhatillah menunjukan 41\% tingkat motivasi belajar IPA dari 61 siswa. Berdasarkan persentase motivasi belajar IPA, bahwa motivasi belajar IPA SD Gugus XII Kecamatan Buleleng belum optimal. 
Persentase keaktifan belajar IPA kelas V SDN 1 Banyuasri menunjukan 39\% tingkat keaktifan belajar IPA dari 37 siswa, SDN 2 Banyuasri menunjukan 40\% tingkat keaktifan belajar IPA dari 37 siswa, SDN 4 Banyuasri menunjukan 41\% tingkat keaktifan belajar IPA dari 36 siswa, SDN 5 Banyuasri menunjukan 42\% tingkat keaktifan belajar IPA dari 35 siswa, dan MIT Mardhatillah menunjukan $41 \%$ tingkat keaktifan belajar IPA dari 61 siswa. Berdasarkan persentase keaktifan belajar IPA, bahwa keaktifan belajar IPA SD Gugus XII Kecamatan Buleleng belum optimal. Motivasi dan keaktifan belajar merupakan faktor yang mempengaruhi hasil belajar.Ketika siswa memiliki motivasi yang tinggi anak tersebut pasti akan aktif belajar serta memperoleh hasil belajar yang bagus dalam proses pembelajaran. Sebaliknya ketika siswa tidak temotivasi dalam belajar siswa menjadi tidak aktif belajar serta mempengaruhi hasil belajar siswa tersebut menjadi kurang bagus. Orang tua dan guru sangat memiliki peran penting dalam mendidik siswa supaya siswa termotivasi untuk belajar, aktif dalam proses pembelajaran sehingga memperoleh hasil belajar yang optimal.

Berdasarkan latar belakang di atas, peneliti akan melaksanakan penelitian korelasi dengan judul "Hubungan Antara Motivasi Belajar dan Keaktifan Belajar dengan Hasil Belajar IPA Siswa Kelas V SD Gugus XII Kecamatan Buleleng”. Dengan harapan, peneliti dapat mengetahui apakah terdapat hubungan yang positif dan signifikan antara motivasi belajar dengan hasil belajar dan keaktifan belajar dengan hasil belajar.

Penelitian ini bertujuan 1) untuk mengetahui hubungan yang signifikan antara motivasi belajar dan hasil belajar IPA siswa kelas V SD Gugus XII Kecamatan Buleleng, 2) untuk mengetahui hubungan yang signifikan antara keatifan belajar dengan hasil belajar IPA siswa kelas V SD Gugus XII Kecamatan Buleleng, 3) untuk mengetahui hubungan yang signifikan antara motivasi belajar dan keaktifan belajar dengan hasil belajar IPA siswa kelas V SD Gugus XII Kecamatan Buleleng 


\section{METODE}

Penelitian ini dilaksanakan di Kelas V SD Gugus XII Kecamatan Buleleng yang terdiri dari SDN 1 Banyuasri, SDN 2 Banyuasri, SDN 4 Banyuasri, SDN 5 Banyuasri, dan MIT Mardatillah pada semester Genap Tahun Pelajaran 2018/2019. Penelitian ini adalah penelitin ex post facto, yaitu penelitian yang tidak memanipulasi data pada variabel bebas atau menggali informasi tentang fakta yang sudah terjadi sebelumnya sehingga penelitian ini tergolong ex post facto yaitu penelitian yang dilakukan untuk meneliti peristiwa yang telah terjadi.

Agung, (2014:56) menyatakan bahwa, Ex Post Facto penelitian yang menggunakan suatu pendekatan dimana gejala (objek) yang diteliti telah ada secara wajar tanpa perlu melakukan eksperimen untuk memunculkan variabel (objek) yang ingin diteliti.

Populasi dalam penelitian ini adalah siswa kelas V di SD yang terdapat pada Gugus XII Kecamatan Buleleng tahun ajaran 2018/2019 yang berjumlah 219 siswa. Dengan cara perhitungan yang sama terhadap tiap populasi maka seluruh sampel pada tiap sub populasi diperoleh dan disajikan pada tabel 1 berikut.

\section{Tabel 1. Sampel Penelitian di Gugus XII Kecamatan Buleleng pada}

\section{Siswa Kelas V}

\begin{tabular}{|c|l|c|c|c|}
\hline No & \multicolumn{1}{|c|}{ Nama Sekolah } & Populasi & Sampel & $\begin{array}{c}\text { Sampel } \\
\text { (Pembulatan) }\end{array}$ \\
\hline $\mathbf{1}$ & SD Negeri 1 Banyuasri & 37 & 27,01 & 27 \\
\hline $\mathbf{2}$ & SD Negeri 2 Banyuasri & 37 & 27,01 & 27 \\
\hline $\mathbf{4}$ & SD Negeri 4 Banyuasri & 36 & 26,28 & 26 \\
\hline $\mathbf{5}$ & SD Negeri 5 Banyuasri & 35 & 25,55 & 26 \\
\hline $\mathbf{6}$ & SD MIT Mardatilah & 61 & 44,53 & 45 \\
\hline & Jumlah & $\mathbf{2 1 9}$ & $\mathbf{1 5 0 , 3 8}$ & $\mathbf{1 5 0}$ \\
\hline
\end{tabular}

Variabel dalam penelitian ini terdiri dari variabel bebas dan variabel terikat. Variabel bebas dalam penelitian ini adalah motivasi dan keaktifan belajar. Sedangkan variabel terikat dalam penelitian ini adalah hasil belajar IPA. Dalam 
penelitian ini metode pengumpulan data yang digunakan adalah metode non tes. Analisis data yang digunakan untuk menguji hipotesis 1 dan 2 adalah uji regresi sederhana sedangkan untuk menguji hipotesis 3 menggunakan analisis regresi ganda. Sebelum melakukan uji hipotesis diawali dengan melakukan uji prayarat analisis meliputi uji normalitas, uji linieritas dan keberartian arah regresi, ujimultikolinieritas dan uji heterokedastisitas.

\section{HASIL DAN PEMBAHASAN}

\section{Hasil}

Deskripsi data dikelompokan menjadi 3, yaitu: (1) motivasi belajar siswa kelas V SD Gugus XII Kecamatan Buleleng, (2) keaktifan belajar siswa kelas V SD Gugus XII Kecamatan Buleleng, (3) hasil belajar IPA siswa kelas V SD Gugus XII Kecamatan Buleleng. Deskripsi data meliputi pengukuran rata-rata hitung, median, modus, standar deviasi, range, nilai minimum, dan nilai maksimum. Berikut adalah penyajian rangkuman statistik deskriptif untuk memudahkan mendiskripsikan masing-masing variabel.

Tabel 2. Rangkuman Statistik Deskriptif Variabel Penelitian

\begin{tabular}{|l|c|c|c|}
\cline { 1 - 2 } Variabel & Motivasi Belajar & $\begin{array}{c}\text { Keaktifan } \\
\text { Belajar }\end{array}$ & Hasil Belajar IPA \\
\cline { 1 - 3 } N & 150 & 150 & 150 \\
\hline Mean & 81,38 & 36,51 & 72,49 \\
\hline Median & 81,00 & 36,00 & 73,00 \\
\hline Modus & $80^{\mathrm{a}}$ & 36 & $68^{\mathrm{a}}$ \\
\hline Standar Deviasi & 7,332 & 3,807 & 9,759 \\
\hline Varians & 53,754 & 14,493 & 95,245 \\
\hline Range & 39 & 15 & 43 \\
\hline Minimum & 63 & 29 & 91 \\
\hline Maksimum & 102 & 44 & 48 \\
\hline
\end{tabular}




\section{Deskripsi Data Motivasi Belajar Siswa Kelas V SD Gugus XII Kecamatan Buleleng}

Gambaran yang jelas mengenai distribusi frekuensi skor motivasi belajar siswa kelas V SD Gugus XII Kecamatan Buleleng dapat dilihat pada gambar 1

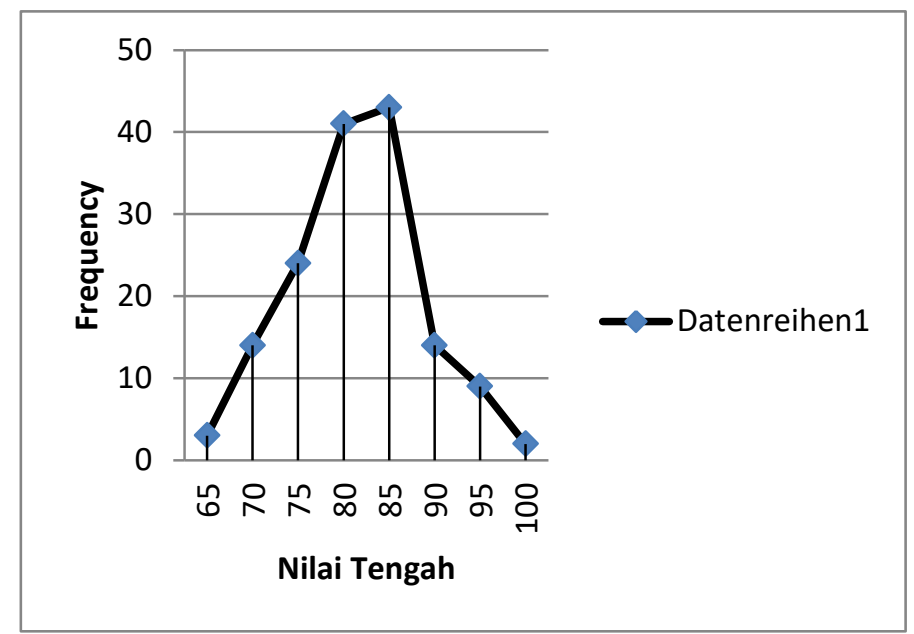

Gambar 1. Polygon Motivasi Belajar Siswa Kelas V SD

Gugus XII Kecamatan Buleleng

Berdasarkan grafik polygon, dapat diketahui bahwa 3 orang siswa memiliki skor antara $63-67,14$ orang siswa memiliki skor antara 68-78, 24 orang siswa memiliki skor antara 73-77, 41 orang siswa memiliki nilai antara $78-82,43$ orang siswa memiliki skor antara $83-87,14$ orang siswa memiliki skor antara 88-92, 9 orang siswa memiliki skor antara 93-97 dan 2 orang siswa memiliki skor antara 98 - 102. Untuk mengetahui kualitas variabel motivasi belajar siswa,nilai rata-rata motivasi belajar dikonversikan kedalam kategori klasifikasi skala lima penilaian acuan ideal teoritik. Berdasarkan hasil konversi,diperoleh bahwa skor rata-rata motivasi belajar siswa, dengan $\mathrm{M}=81,38$ tergolong kedalam kriteria“'Sedang”.

\section{Deskripsi Data Keaktifan Belajar Siswa Kelas V SD Gugus XII Kecamatan}

\section{Buleleng}

Data tentang keaktifan belajar siswa dengan $n=150$, diperoleh rata-rata sebesar 36,51, median sebesar 36,00 modus sebesar 36, nilai maksimum 44, nilai 
minimum 29, rentangan 15, banyak kelas 8, dan panjang kelas interval 2.Berdasarkan data tersebut dapat dibentuk distribusi frekuensi skor kekatifan belajar siswa kelas V SD Gugus XII Kecamatan Buleleng. Gambaran yang jelas mengenai distribusi frekuensi skor keaktifan belajar siswa kelas V SD Gugus XII Kecamatan Buleleng dapat dilihat pada gambar berikut.

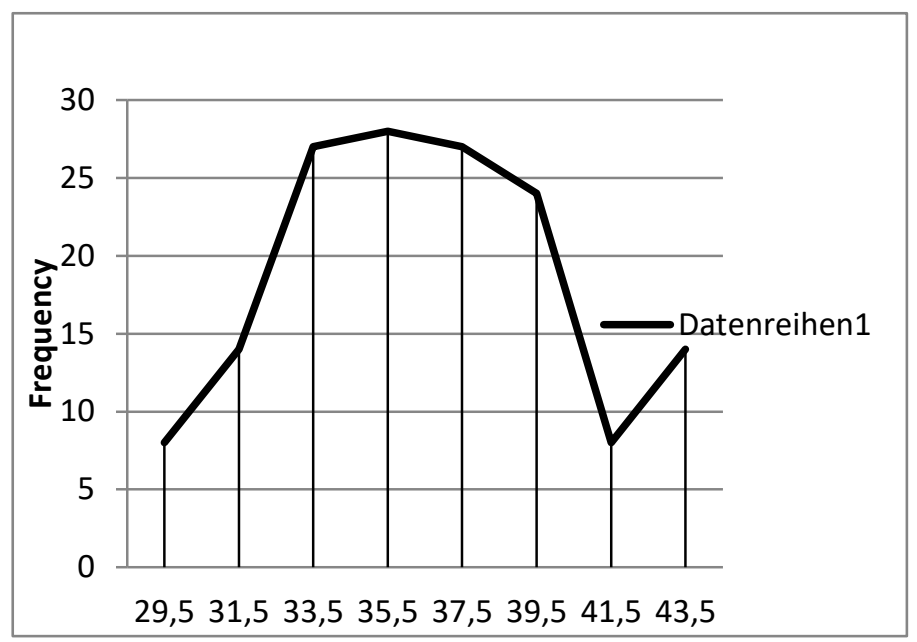

Gambar 2. Polygon Keaktifan Belajar Siswa Kelas V SD

Gugus XII Kecamatan Buleleng

Berdasarkan grafik polygon 2, dapat diketahui bahwa 8 orang siswa memiliki skor antara 29 - 30, 14 orang siswa memiliki skor antara 31-32, 27 orang siswa memiliki skor antara 33-34, 28 orang siswa memiliki nilai antara $35-36,27$ orang siswa memiliki skor antara 37-38, 24 orang siswa memiliki skor antara 39-40, 8 orang siswa memiliki skor antara 41-42 dan 14 orang siswa memiliki skor antara 43-44. Untuk mengetahui kualitas variable kekatifan belajar siswa, nilai rata-rata keaktifan belajar dikonversikan kedalam kategori klasifikasi skala lima penilaian acuan ideal teoritik. Berdasarkan hasil konversi, diperoleh bahwa skor rata-rata keaktifan belajar siswa, dengan $\mathrm{M}=36,51$ tergolong kedalam kriteria“"Sedang”. 


\section{Deskripsi Data Hasil Belajar IPAKelas V SD Gugus XII Kecamatan Buleleng}

Data tentang hasil belajar IPA siswa dengan $n=150$, diperoleh rata-rata sebesar 72,49, median sebesar 73,00 modus sebesar 68, nilai maksimum 91, nilai minimum 52, rentangan 40, banyak kelas 8, dan panjang kelas interval 5. Berdasarkandata tersebut dapat dibentuk distribusi frekuensi skor hasil belajar IPA siswa kelas V SD Gugus XII Kecamatan Buleleng. Gambaran yang jelas mengenai distribusi frekuensi skor hasil belajar IPA siswa kelas V SD Gugus XII Kecamatan Buleleng dapatd ilihat pada gambar 3.

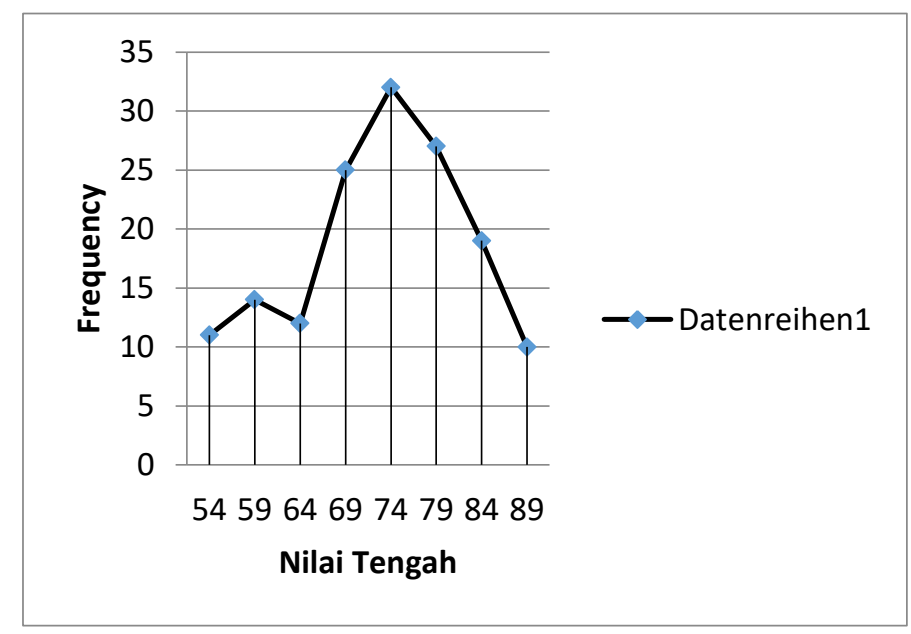

Gambar 3. Polygon Hasil Belajar IPA Siswa Kelas V SD

Gugus XII Kecamatan Buleleng

Berdasarkan grafik polygon 4.3, dapat diketahui bahwa 11orang siswa memiliki skor antara 52-53, 14 orang siswa memiliki skor antara 57-61, 12 orang siswa memiliki skor antara 62-66, 25 orang siswa memiliki nilai antara 67-71, 32 orang siswa memiliki skor antara $72-76,27$ orang siswa memiliki skor antara 77-81, 19 orang siswa memiliki skor antara 82-86 dan 19 orang siswa memiliki skor antara 87-91. Untuk mengetahui kualitas variable hasil belajar IPA siswa,nilai rata-rata hasil belajar IPA dikonversikan kedalam kategori klasifikasi skala lima penilaian acuan ideal teoritik. Berdasarkan hasil konversi, diperoleh bahwas skor rata-rata hasil belajar IPA siswa, dengan $\mathrm{M}=72,49$ tergolong kedalam kriteria“Tinggi". 
Data motivasi belajar,keaktifan belajar dan hasil belajar IPA yang telah terkumpul kemudian dilakukan pengujian hipotesis menggunakan uji regresi sederhana untuk hipotesis 1 dan 2 sedangkan hipotesis 3 menggunakan uji regresi ganda dibantu dengan program SPSS Statistics 21.0 for Windows. Sebelum pengujian hipotesis penelitian harus memenuhi prasyarat analisis dengan melakukan uji normalitas, uji linieritas dan keberartian arah regresi, uji multikolinieritas, dan uji heterokedastisitas. Uji normalitas dilakukan untuk mengetahui data hasil penelitian yang didapatkan berdistribusi normal atau tidak. Apabila data berdistribusi normal maka dapat dilanjutkan dengan melakukan pengujian hipotesis. hasil analisis menunjukkan bahwa keseluruhan nilai signifikansi dari perhitungan Kolmogorov-Smirnov sebesar 0,059 lebih tinggi dari $0,05(0,059>0,05)$. Hal ini berarti, residual data keseluruhan berasal dari populasi yang berdistribusi secara normal.

Selanjutnya untuk uji lineritas dan keberartian arah regresi diperoleh hasil analisis uji linieritas garis regresi, menunjukan bahwa untuk semua hubungan variabel, Linierity dibawah $0,05(\mathrm{p}<0,05)$ yaitu $\mathrm{X}_{1} \mathrm{Y}=0,000$ dan $\mathrm{X}_{2} \mathrm{Y}=0,00$. Dengan demikian, hubungan antara motivasi belajar dan keaktifan belajar siswa terhadap hasil belajar IPA siswa kelas V SD Gugus XII Kecamatan Buleleng mempunyai hubungan yang linear, sehingga dapat disintesiskan bahwa analisis uji regresi dapat dilanjutkan. Sedangkan nilai Deviation from Linearity untuk semua pasangan variabel bebas dan variabel terikat lebih besar dari $0,05(\mathrm{p}>0,05)$ yaitu $\mathrm{X}_{1} \mathrm{Y}=0,060$ dan $\mathrm{X}_{2} \mathrm{Y}=0,835$. Hal ini berarti koefisien arah regresi berarti. Dengan kata lain, terdapat hubungan fungsional yang signifikan antara motivasi belajar dan keaktifan belajar siswa terhadap hasil belajar IPA siswa kelas V SD Gugus XII Kecamatan Buleleng.

Hasil perhitungan uji multikolinieritas menunjukkan bahwa nilai VIF antara variabel motivasi belajar terhadap hasil belajar IPA siswa adalah 1,230 dengan nilai tolerance 0,813 dan variabel keaktifan belajar terhadap hasil belajar IPA siswa adalah 1,230, dari hasil analisis diatas, nilai VIF berada dibawah 10 dan Tolerance diatas 0,1 , hal ini berarti seluruh data bebas dari gejala multikolineritas dan memenuhi uji prasyarat analisis. Sedangkan uji heteroskedastisitas menunjukkan bahwa nilai signifikan absolute residual antara variabel motivasi 
belajar terhadap hasil belajar IPA siswa adalah 0,075 dan signifikan absolute residual antara variabel keaktifan belajar terhadap hasil belajar IPA siswa adalah 0,101, dari hasil analisis diatas, nilai signifikansinya di atas 0,05 maka tidak mengandung gejala heteroskedastisitas dan memenuhi uji prasyarat analisis.

Tabel 3.

\section{Hasil Analisis Hipotesis 1}

Model Summary

\begin{tabular}{|c|c|c|c|c|c|c|c|c|c|}
\hline \multirow[b]{2}{*}{ Model } & \multirow[b]{2}{*}{$\mathrm{R}$} & \multirow[b]{2}{*}{$\begin{array}{c}\mathrm{R} \\
\text { Square }\end{array}$} & \multirow[b]{2}{*}{$\begin{array}{l}\text { Adjusted } \\
\text { R Square }\end{array}$} & \multirow[b]{2}{*}{$\begin{array}{l}\text { Std. Error of } \\
\text { the Estimate }\end{array}$} & \multicolumn{5}{|c|}{ Change Statistics } \\
\hline & & & & & $\begin{array}{c}\text { R Square } \\
\text { Change }\end{array}$ & F Change & df1 & df 2 & $\begin{array}{l}\text { Sig. F } \\
\text { Change }\end{array}$ \\
\hline 1 & $.768^{\mathrm{a}}$ & .591 & .588 & 6.266 & .591 & 213.451 & 1 & 148 & .000 \\
\hline
\end{tabular}

a. Predictors: (Constant), Motivasi Belajar

Hipotesis pertama dianalisis menggunakan uji regresi sederhana dibantu dengan menggunakan program SPSS Statistic 21.0 for Windows. Berdasarkan hasil analisis diperoleh nilai signifikan antara motivasi belajar dengan hasil belajar IPA sebesar 0,000 jika dibandingkan dengan 0,05 maka 0,000 kurang dari $0,05(0,000<0,05)$ dengan nilai koefisien $\mathrm{R}$ sebesar $0,768>0,05$ sehingga nilai $\mathrm{r}$ hitung signifikan. Koefisien korelasi R bernilai 0,768 yang berarti memiliki nilai korelasi hubungan sangat kuat antara motivasi belajar dengan hasil belajar IPA siswa kelas V SD Gugus XII Kecamatan Buleleng.

\section{Tabel 4.}

\section{Hasil Analisis Hipotesis 2}

Model Summary

\begin{tabular}{|c|c|c|c|c|c|c|c|c|c|}
\hline \multirow[b]{2}{*}{ Model } & \multirow[b]{2}{*}{$\mathrm{R}$} & \multirow[b]{2}{*}{$\begin{array}{c}\mathrm{R} \\
\text { Square }\end{array}$} & \multirow[b]{2}{*}{$\begin{array}{l}\text { Adjusted R } \\
\text { Square }\end{array}$} & \multirow[b]{2}{*}{$\begin{array}{l}\text { Std. Error of } \\
\text { the Estimate }\end{array}$} & \multicolumn{5}{|c|}{ Change Statistics } \\
\hline & & & & & $\begin{array}{l}\text { R Square } \\
\text { Change }\end{array}$ & $\begin{array}{c}\mathrm{F} \\
\text { Change }\end{array}$ & df1 & df2 & $\begin{array}{c}\text { Sig. F } \\
\text { Chang } \\
\text { e }\end{array}$ \\
\hline 1 & $.658^{\mathrm{a}}$ & .433 & .429 & 7.373 & .433 & 113.049 & 1 & 148 & .000 \\
\hline
\end{tabular}

a. Predictors: (Constant), Keaktifan Belajar 
Hipotesis kedua dianalisis menggunakan uji regresi sederhana dibantu dengan menggunakan program SPSS Statistic 21.0 for Windows. Berdasarkan hasil analisis, diperoleh nilai signifikan antara keaktifan belajar dengan hasil belajar IPA sebesar 0,000 jika dibandingkan dengan 0,05 maka 0,000 kurang dari $0,05(0,000<0,05)$ dengan nilai koefisien $\mathrm{R}$ sebesar $0,658>0,05$ sehingga nilai $\mathrm{r}$ hitung signifikan. Koefisien korelasi R bernilai 0,658 yang berarti memiliki nilai korelasi hubungan sangat kuat antara keaktifan belajar dengan hasil belajar IPA siswa kelas V SD Gugus XII Kecamatan Buleleng.

Tabel 5.

Hasil Analisis Hipotesis 3

Model Summary

\begin{tabular}{c|c|c|c|c|c|c|c|c|c}
\hline \multirow{2}{*}{ Model } & \multirow{2}{*}{$\mathrm{R}$} & $\mathrm{R}$ & Adjusted $\mathrm{R}$ & Std. Error of \\
Square & Square & the Estimate & $\begin{array}{c}\text { R Square } \\
\text { Change }\end{array}$ & $\begin{array}{c}\mathrm{F} \\
\text { Change }\end{array}$ & $\mathrm{df1}$ & $\mathrm{df2}$ & $\begin{array}{c}\text { Sig. F } \\
\text { Change }\end{array}$ \\
\hline 1 & $.849^{\mathrm{a}}$ & .721 & .717 & 5.189 & .721 & 190.079 & 2 & 147 & .000 \\
\hline
\end{tabular}

a. Predictors: (Constant), Keaktifan Belajar, Motivasi Belajar

b. Dependent Variable: Hasil Belajar IPA

Hipotesis ketiga dianalisis menggunakan uji regresi ganda dibantu dengan menggunakan program SPSS Statistic 21.0 for Windows.Berdasarkan hasil perhitungan didapat koefisien korelasi secara bersama-sama antara motivasi belajar siswa dan keaktifan belajar siswa terhadap hasil belajar IPA siswa kelas V SD Gugus XII Kecamatan Buleleng sebesar 0,849 yang berarti memiliki korelasi atau hubungan sangat kuat, untuk mengetahui koefisien ini signifikan atau tidak, maka dilakukan uji F. perhitungan didapat nilai $F_{\text {hitung }}$ sebesar 190,079. Nilai ini kemudian dibandingkan dengan nilai $\mathrm{F}_{\text {tabel, }}$, pada tabel didapat nilai kritis sebesar 3,06 untuk dk penyebut $=150-3=147 \mathrm{dan} \mathrm{dk}$ pembilang $=3-1=2$ pada taraf kesalahan 5\%. Karena nilai $F_{\text {hitung }}$ lebih besar dari pada nilai $F_{\text {tabel }}(190,079>$ 3,06) maka dapat disintesikan bahwa korelasi $\mathrm{X}_{1}$ dan $\mathrm{X}_{2}$ terhadap $\mathrm{Y}$ adalah signifikan. 


\section{Pembahasan}

\section{Hubungan Antara Motivasi Belajar Dengan Hasil Belajar IPA Siswa Kelas V SD Gugus XII Kecamatan Buleleng}

Berdasarkan hasil analisis data diperoleh bahwa terdapat hubungan antara motivasi belajar dengan hasil belajar IPA. Motivasi memiliki peran penting dalam tercapai hasil belajar yang bagus. Siswa yang termotivasi untuk belajar akan semangat mengikuti proses pelajaran namun sebaliknya siswa yang tidak termotivasi akan merasa jenuh dan bosan mengikuti proses pembelajaran. Seperti yang dikemukan oleh Lilyanti,dkk (2016) motivasi belajar adalah keseluruhan daya penggerak psikis dalam diri siswa yang menimbulkan kegiatan belajar, menjamin kelangsungan belajar demi mencapai satu tujuan. Motivasi juga bisa berasal dari dalam diri dan dari orang lain, baik itu guru, keluarga dan teman. Motivasi meruapakan suatu dorongan dalam diri atau penggerak untuk melakukan suatu tindakan sehingga mencapai hasil yang diingankan Menurut Amni,dkk (2017), motivasi merupakan dorongan seseorang secara sadar atau tidak sadar untuk melakukan sesuatu kegiatan untuk mencapai tujuannya. Motivasi dalam diri siswa sangatlah berperan agar siswa terdorong melakukan kegiatan dalam proses belajar mengajar sehingga siswa memperoleh hasil belajar yang bagus.

Hadi (2017) menyatakan, hasil belajar adalah hasil yang diperoleh siswa dari hasil tes atau evaluasi setelah proses belajar mengajar yang dinyatakan dalam bentuk angka atau skor . Hasil belajar terdiri dari 2 faktor yaitu faktor eksternal dan internal, adapun faktor tersebut yaitu salah satunya motivasi. Hasil belajar yang diperoleh siswa tergantung dari motivasi siswa untuk belajar. Siswa memiliki motivasi yang beragam dalam mengikuti proses pembelajaran, hal tersebut tentu akan berdampak pada hasil belajar yang diperoleh siswa. Menurut Pindo dan Rinci (2018), hasil belajar adalah pencapaian bentuk perubahan perilaku yang cenderung menetap dari ranah kognitif, afektif, dan psikomotorik dari proses belajar yang dilakukan dalam waktu tertentu. Siswa dalam proses pembelajaran bukan hanya belajar ilmu pengetahuan saja namun siswa diharapkan memiliki sikap dan karakter yang baik serta memiliki ketrampilan sehingga mampu memperoleh hasil belajar yang bagus. 
Temuan ini didukung oleh penelitian Anike \& Emilia (2015) bahwa terdapat hubungan yang signifikan antara motivasi belajar dengan hasil belajar IPA. Yuliany (2018) juga melakukan peneletian yang menyatakan bahwa terdapat hubungan antara motivasi belajar terhadap hasil belajar siswa. Berdasarkan penelitian yang telah dilakukan dan diperkuat oleh pendapat di atas, maka hubungan antara motivasi belajar signifikan terhadap hasil belajar IPA.

\section{Hubungan Antara Keaktifan Belajar Dengan Hasil Belajar IPA Siswa Kelas V SD Gugus XII Kecamatan Buleleng}

Berdasarkan hasil analisis data di peroleh bahwa terdapat hubungan antara keaktifan belajar dengan hasil belajar IPA. Keaktifan dalam proses pembelajaran juga menentukan perolehan hasil belajar yang bagus. Semakin siswa aktif dalam proses pembelajaran semakin baik pula hasil belajar yang akan diperoleh. Keaktifan merupakan suatu tindakan yang dilakukan seseorang melibatkan aktifitas fisik, emosional dan pikiran. Siswa yang aktif dalam belajar akan lebih menonjol dibandingkan dengan siswa yang tidak aktif dalam belajar, hasil belajar yang diperolehpun akan berbeda maka keaktifan sangatlah penting dalam proses pembelajaran selain untuk memperoleh hasil belajar yang bagus keaktifan juga diperlukan untuk mengetahui seberapa paham siswa terhadap materi /tugas yang diberikan oleh guru.

Alfa (2017) menyatakan, keaktifan siswa selama mengikuti proses belajar mengajar merupakan salah indikator adanya keinginan atau motivasi siswa untuk belajar. Menurut Dean, dkk (2016) keaktifan belajar merupakan bentuk segala kegiatan yang dilakukan siswa dalam proses pembelajaran, baik secara fisik dan psikis maupun kegiatan yang mudah diamati maupun sulit diamati. Kurikulum 2013 menuntut siswa untuk aktif dalam setiap proses pembelajaran sedangkan guru hanya memfasilitasi, mendampingi serta membimbing siswa, maka dari itu guru perlu melakukan upaya agar siswa bisa aktif dalam setiap proses pembelajaran sehingga mencapai hasil belajar yang bagus.

Menurut Simanjorang (2018), hasil belajar adalah kemampuan-kemampuan yang dimiliki siswa setelah ia menerima pengalaman belajarnya. Ariyanto (2016) menyatakan, hasil belajar adalah perubahan berupa kecakapan fisik, mental, 
intelektual yang berproses dari kegiatan belajar. Hasil belajar diperoleh bukan hanya dengan menjawab soal yang diberikan guru dan memperoleh hasil, tetapi hasil belajar diperoleh dengan berbagai macam kriteria penilaian salah satunya aktif dalam kegiatan pembelajaran. Keaktifan dalam pembelajaran sangatlah penting agar terciptanya situasi kelas yang kondusif. Seamkin aktif siswa dalam proses pembelajaran semakin bagus pula hasil belajar yang diperoleh.

Temuan ini didukung oleh penelitian Nanda (2017) menunjukan bahwa terdapat hubungan yang signifikan antara keaktifan belajar dengan hasil belajar. Berdasarkan penelitian yang telah dilakukan dan diperkuat oleh pendapat di atas, maka hubungan antara keaktifan belajar signifikan terhadap hasil belajar IPA.

\section{Hubungan Antara Motivasi Belajar dan Keaktifan Belajar Dengan Hasil Belajar IPA Siswa Kelas V SD Gugus XII Kecamatan Buleleng}

Berdasarkan hasil analisis data diperoleh bahwa terdapat hubungan antara motivasi belajar dan keaktifan belajar dengan hasil belajar IPA. Hasil belajar merupakan unsur yang penting dalam penentu untuk mengetahui seberapa kemampuan siswa selama mengikuti proses kegiatan pembelajaran. Konita,dkk (2018) mengemukakan, hasil belajar merupakan suatu perubahan yang terjadi pada siswa dalam bentuk kemampuan interaksi dari tindakan belajar dan mengajar. Hasil belajar dipengaruhi oleh 2 faktor internal dan eksternal faktorfaktor tersebut sangat mempengaruhi hasil belajar adapun dua diantaranya yaitu motivasi dan keaktifan belajar, motivasi sangat mempengaruhi hasil belajar, setiap siswa memilki motivasi yang berbeda-beda ketika mengikuti kegiatan pembelajara. Amni,dkk (2017) mengmukakan, motivasi merupakan salah satu faktor yang sangat penting untuk mendorong semangat belajar siswa ,sehingga siswa yang mempunyai motivasi belajar akan mengerti dengan apa yang menjadi tujuan dalam belajar. Motivasi dalam proses pembelajaran sangatlah dibutuhkan oleh siswa. Siswa yang memiliki motivasi akan cendurung bersemangat mengikuti proses pembelajaran, tekun mengerjakan tugas, mampu memecahkan masalah yang diberikan oleh guru. Berbeda dengan siswa yang tidak termotivasi akan cenderung malas mengerjakan tugas, merasa kesulitan memecahkan masalah yang diberikan oleh guru. 
Motivasi juga bisa menjadi pemicu siswa menjadi aktif dalam proses pembelajaran, keaktifan dalam proses pembelajaran juga merupakan faktor yang mempengaruhi hasil belajar. Zakiah (2017) menyatakan, siswa aktif adalah siswa yang terlibat secara fisik, psikis, intelektual dan emosional secara terus menerus dalam proses pembelajaran. Pada kurikulum 2013 siswa diharapkan aktif dalam proses pembelajaran sedangkan guru hanya memfasilitasi. Siswa yang aktif dalam proses pembelajaran akan lebih unggul dibandingkan siswa yang tidak aktif begitu pula perolehan hasil belajar yang diperoleh tentu akan berbeda.

Motivasi dan keaktifan sangatlah penting dalam proses pembelajaran, siswa yang memilki motivasi tentu akan aktif dalam proses pembelajaran sehingga hasil belajar yang diproleh akan bagus. Berdasarkan paparan tersebut hasil belajar dipengaruhi oleh banyak faktor dua diantaranya motivasi dan keaktifan, dengan demikian hubungan antara motivasi dan keaktifan terhadap hasil belajar IPA siswa kelas V SD Gugus XII Kecamatan Buleleng disimpulkan kedua faktor tersebut memberikan kontribusi signifikan terhadap hasil belajar IPA siswa.

Temuan dalam penelitian ini didukung oleh penelitian yang dilakukan oleh Anike \& Emilia (2015) bahwa terdapat hubungan yang signifikan antara motivasi belajar dengan hasil belajar IPA. Serta Hasil penelitian ini sesuai dengan penelitian yang dilakukan Nanda (2017) menunjukan bahwa terdapat hubungan yang signifikan antara keaktifan belajar dengan hasil belajar. Berdasarkan penelitian yang telah dilakukan dan diperkuat oleh pendapat di atas, maka hubungan antara motivasi belajar dan keaktifan belajar signifikan terhadap hasil belajar IPA.

\section{SIMPULAN}

Berdasarkan hasil pengujian hipotesis dan pembahasan, maka simpulan dari penelitian ini adalah sebagai berikut. Pertama, terdapat hubungan yang signifikan antara motivasi belajar dengan hasil belajar IPA siswa kelas V SD Gugus XII Kecamatan Buleleng, dengan koefisien korelasi R sebesar 0,768 dan sumbangan variabel kontribusi sebesar 59,1\%. Kedua, terdapat hubungan yang positif dan signifikan antara kekatifan belajar dengan hasil belajar IPA siswa kelas V SD 
Gugus XII Kecamatan Buleleng, dengan koefisien korelasi R sebesar 0,658, dan sumbangan variabel kontribusi sebesar 43,3\%. Ketiga terdapat hubungan yang positif dan signifikan antara motivasi belajar dan kekatifan belajar dengan hasil belajar IPA siswa kelas V SD Gugus XII Kecamatan Buleleng, dengan koefisien korelasi R sebesar 0,849 dan sumbangan variabel kontribusi sebesar 72,1\%.

Berdasarkan hasil penelitian ini, maka dapat diajukan beberapa saran sebagai berikut. Guru selain mengajarkan materi pembelajaran IPA, guru perlu memberikan motivasi bagi siswa agar siswa lebih semangat belajar dan termotivasi dalam proses pembelajaran. Guru bisa menggunakan berbagai macam model-model pembelajaran agar siswa termotivasi mengikuti proses pembelajaran sehingga siswa bisa memperoleh hasil belajar yang bagus. Guru juga perlu memperhatikan keaktifan siswa, guru dapat melakukan kegiatan diskusi, melakukan percobaan, pembelajaran berbasis masalah untuk meningkatkan keaktifan siswa dalam proses pembelajaran sehingga siswa aktif dalam kegiatan pembelajaran dan memperoleh hasil belajar yang bagus.

\section{Daftar Pustaka}

Achyanadia, Septy. 2013. Hubungan Kebiasaan Belajar dan Motivasi Belajar dengan Hasil Belajar IPA Siswa Kelas VII SMP Negeri 1 Ciseeng. Jurnal Teknologi Pendidikan. Volumen 2. Nomor 2(hlm 7)

Agung, A.A. Gede. 2014. Buku Ajar Metodologi Penelitian Pedidikan. Malang: Aditya Media Publising.

Agung, A.A. Gede. 2015. Statistik Dasar untuk Pendidikan.Yogyakarta: Deepublising.

Amni, Asih, dan Samsul. 2017. Hubungan Antara Motivasi Belajar dengan Minat Belajar Siswa Kelas IV SDN Poris Gaga 05 Kota Tangerang. Jurnal JPSD. Volume 4, Nomor 1.

Anike \& Emelia. 2015. Hubungan Motivasi Belajar dengan Hasil Belajar Siswa pada Mata Pelajaran IPA di Sekolah Dasar. Jurnal Pendidikan Dasar Perkhasa, Volume 1, Nomor 1(hlm 9). 
Ariyanto, Metta.2016. Peningkatan Hasil Belajar IPA Materi Kenampakan Rupa Bumi Menggunakan Model Scramble.Jurnal Profesi Pendidikan Dasar .Volume 3, Nomor 2 (hlm 135).

Candiasa, I Made. 2011. Statistik Multivariat Disertai Aplikasi SPSS.Singaraja: Unit Penerbitan Universitas Pendidikan Ganesha.

Daen, Dibia,Putrini. 2016. Implementasi Pembelajaran Quantum Teaching untuk Meningkatkan Keaktifan dan Hasil Belajar IPS Siawa Kelas V SD. $e$ Journal PGSD, Volume 4, Nomor 1(hlm 4).

Ermelinda \& Kristina.2017.Hubungan antara Minat dan MotivasiBelajar dengan Hasil Belajar IPA pada Siswa SD. Journal of Education Technology. Vol. 1 Nomor 4 (hlm 232).

Fadjrin, Nanda Noor. 2017.Hubungan Keaktifan Belajar di Sekolah terhadap

Hasil Belajar Matematika Siswa Kelas VIII.Jurnal MathGram Matematika, Volume 2, Nomor 1.

Konita dan Ade. 2018.Pengaruh Home Visit dan Motivasi Belajar Terhadap Hasil

Belajar Siswa di SDIT Harapan Bunda Purwekerto.Jurnal Ekonomi, Bisnis, dan Akuntansi (JEBA), Volume 20, Nomor 01.

Lilyanti,dkk.2016. Pengaruh Pengetahuan Awal Kecerdasan Emosionel dan Motivasi Belajar Terhadap Hasil Belajar IPA Siswa Kelas VIII SMP Negeri 3 Parigi. e-Jurnal Mitra Sains, Volume 4, Nomor 3(hlm 60)

N.R, Alfa Zayyin. 2017. Meningkatkan Keaktifan dan Hasil Belajar Matematika dengan Model Pembelajaran Kooferatif Tipe Group Investigation. Jurnal Pendidikan Matematik, Vol 5,No 1(hlm 11).

Pranoto, Hadi.(2017). Peningkatan Hasil Belajar Siswa Melalui Model Pembelajaran Examples Non Examples Pada Mata Pelajaran IPA Siswa Kelas VI B Semester 1 SD Negeri Turitempel Tahun Pelajaran 2016/2017. Jurnal Ilmiah Pendidikan Dasar, Volume 7, Nomor 1(hlm.45).

Pindo dan Rinci. 2018. Meningkatkan Hasil Belajar Siswa dengan Alat Peraga Pada Mata Pelajaran IPA Kelas IV SDN Nomor 14 Simbolon Purba. Volume 8, Nomor 2 (hlm 124).

Ramlah, dkk.2014.Pengaruh Gaya Belajar dan Keaktifan Siswa Terhadap Prestasi Belajar Matematika ( Survey Pada SMP Negeri di Kecamatan Klari Kabupaten Karawang), Jurnal Ilmiah Solusi, Volume 1, Nomor 3(hlm.70) 
Sardiman.2016. Interaksi\&Motivasi Belajar Mengajar. Jakarta: Rajawali Pers

Simanjorang, Edwin.2018.Meningkatkan Hasil Belajar dan Keaktifan Belajar IPA Melalui Metode Simulasi Berbasis Bioedutainment Pada Siswa. Jurnal Tabularasa PPS UNIMED, Vol.15 No.1(hlm 34).

Sudjana, Nana. 1989. Cara Belajar Siswa Aktif dalam Proses Belajar Mengajar. Bandung: Penerbit CV. SINAR BARU

Yuliany,Nur.2018.Hubungan antara Motivasi Belajar dan Hasil Belajar Siswa SDN Emmy Saelan Makassar.Jurnal Pendidikan Dasar Islam Vol. 5,No. 2,hlm(126).

Zakiah,Linda. 2017. Hubungan Keaktifan dalam Kegiatan Pramuka dan Motivasi Belajar Pendidikan Kewarganegaraan pada Siswa Kelas IV Sekolah Dasar. Jurnal Pendidikan Dasar, Volume 8, hlm 149. 